\title{
The Action Pattern of Sugarcane-Leaf Amylase
}

\author{
Alex G. Alexander ${ }^{1}$
}

\section{INTRODUCTION}

Since the discovery of a powerful sugarcane amylase in $1963(1)^{2}$, the presence of this enzyme has been interpreted as a biochemical necessity $(3,6,5,2)$. Assuming that maximum sucrose synthesis cannot tolerate a second major carbohydrate-storage mechanism, it was proposed that amylase plays a key role in holding starch accumulations to a minimum.

It is generally accepted that the disaccharide maltose is a product of two amylases, "alpha" and "beta", which act upon starch $(16,17,19)$. $\beta$-amylase hydrolyzes the alternate alpha $(1 \rightarrow 4)$-glycosidic bonds of the amylose portion and readily yields maltose. A-amylase yields oligosaccharides by attacking the glycosidic linkages deep within the polysaccharide chain (15, p. 434). Maltose is produced quite slowly.

Sugarcane catalysts such as starch phosphorylase (6) and Q-enzyme (4) have helped complete an overall picture of starch synthesis plus degradation (7). The role of amylase in this sequence should be confined to the catalytic formation of disaccharides or oligosaccharides. However, recent findings show that the monosaccharide glucose is a major and direct product of cane amylase. This discovery led to a reevaluation of the enzyme's role based upon a nearly unique amylase action pattern.

\section{MATERIALS AND METHODS}

\section{ENZYME PREPARATION AND ASSAY}

Amylase was extracted with water from lyophilized leaf tissues of 14week-old plants of the variety P.R. 980. Most of the amylase samples used during this study were precipitated from clarified extracts between 48- and 62 -percent saturation by ammonium sulfate, at $\mathrm{pH} 7.0$ and $22^{\circ} \mathrm{C}$. Enzyme samples were dialyzed overnight against distilled water. In some instances the amylase solutions were filtered through $1.5 \times 24-\mathrm{cm}$. columns of G-200 Sephadex ${ }^{3}$. The latter step permits good resolution of amylase from noncatalytic protein (9). Neither dialysis nor gel filtration caused appreciable inactivation.

Preliminary assays were based on the amount of reducing sugar formed under standardized conditions. The standard digest was composed as

${ }^{1}$ Associate Plant Physiologist, Agricultural Experiment Station, University of Puerto Rico, Río Piedras, P.R.

${ }^{2}$ Italic numbers in parentheses refer to Literature Cited, pp. 165-6.

${ }^{3}$ Sephadex was supplied by the Farmacia of Fine Chemicals, Rochester, Minn. Mention of this trade name implies no endorsement or warranty. 
follows: $1.0 \mathrm{ml}$. of $0.1-\mathrm{M}^{4}$ acetate buffer, $\mathrm{pH} 6.0 ; 1.0 \mathrm{ml}$. of 1-percent soluble potato starch ${ }^{5}$, and $0.25 \mathrm{ml}$. of enzyme preparation. The reaction proceeded for 1 hour at $37^{\circ} \mathrm{C}$. Reducing sugars were determined by the dinitrosalicylic acid technique of Sumner (21), as modified for cane amylase (5). Protein content of the enzyme solution was measured by the technique of Sutherland et al. (22). Amylase action was expressed as specific activity (activity units per milligram of protein).

Larger digest volumes were used for chromatographic studies. Aliquots of the active digest were withdrawn at intervals ranging from 5 minutes to 72 hours and inactivated by immersion in boiling water. Inactivation of amylase poses a problem since a product is formed briefly even while the

TABLE 1.-Chemical and heat inactivation of sugarcane amylase $e^{1}$

\begin{tabular}{|c|c|c|c|c|c|c|c|}
\hline \multirow{2}{*}{ Treatment } & \multicolumn{7}{|c|}{ Micromoles of additive per milliliter of digest- } \\
\hline & 0 & 0.0001 & 0.001 & 0.01 & 0.1 & 1.0 & 10.0 \\
\hline K1 & 442 & 440 & 423 & 404 & 367 & 223 & 26 \\
\hline $\mathrm{HgCl}_{2}$ & 442 & 392 & 79 & 50 & 0 & 0 & 0 \\
\hline \multirow{2}{*}{ Treatment } & \multicolumn{7}{|c|}{ Minutes in boiling water- } \\
\hline & 0 & 1 & 2 & 4 & 8 & 12 & \\
\hline Heat & 440 & 29 & 0 & 0 & 0 & 0 & \\
\hline
\end{tabular}

${ }^{1}$ Enzyme values are expressed as specific activity.

sample is standing in boiling water. Nevertheless, heat treatments were found superior to inactivation by chemical additives (table 1).

\section{CHROMATOGRAPHY OF AMYLASE PRODUCTS}

Enzyme products were identified by paper chromatography using a solvent mixture of butanol-pyridine-water $(6: 4: 3, v / v)$. Each of the solvent components was redistilled under glass and all papers were thoroughly washed prior to receiving samples. Reference sugars were established by spotting 12 to $16 \lambda$ of 1-percent maltose and glucose solution on No. 1 Whatman filter paper. Reference solutions were made up in boiled enzyme

${ }^{4}$ The letter M signifies "molar" herein.

${ }^{5}$ Starch solution was prepared as follows: Exactly $1 \mathrm{gm}$. of A.C.S.-grade soluble potato starch was placed in a $200-\mathrm{ml}$. pyrex culture tube. The starch was wetted with $5 \mathrm{ml}$. of ethanol and taken up in $50 \mathrm{ml}$. of $0.5-\mathrm{N} \mathrm{NaOH}$. Complete solution was accomplished by placing the tube in boiling water and allowing it to stand for 3 minutes. The solution was cooled, adjusted to $\mathrm{pH} 7$ with $0.5 \mathrm{~N} \mathrm{H}_{2} \mathrm{SO}_{4}$, and brought to $100 \mathrm{ml}$. with water. Solutions of amylose, amylopectin, cornstarch, inulin, and glycogen were prepared in like manner. 
preparation. From 20 to $25 \lambda$ of inactivated digest usually sufficed to yield well-formed spots. The descending technique was employed for all experiments, with irrigation periods ranging from 36 to 48 hours.

Sugars were revealed on dryed chromatograms by the silver nitrate "dip" method of Dube and Nordin (10). Sheets were first immersed in acetone

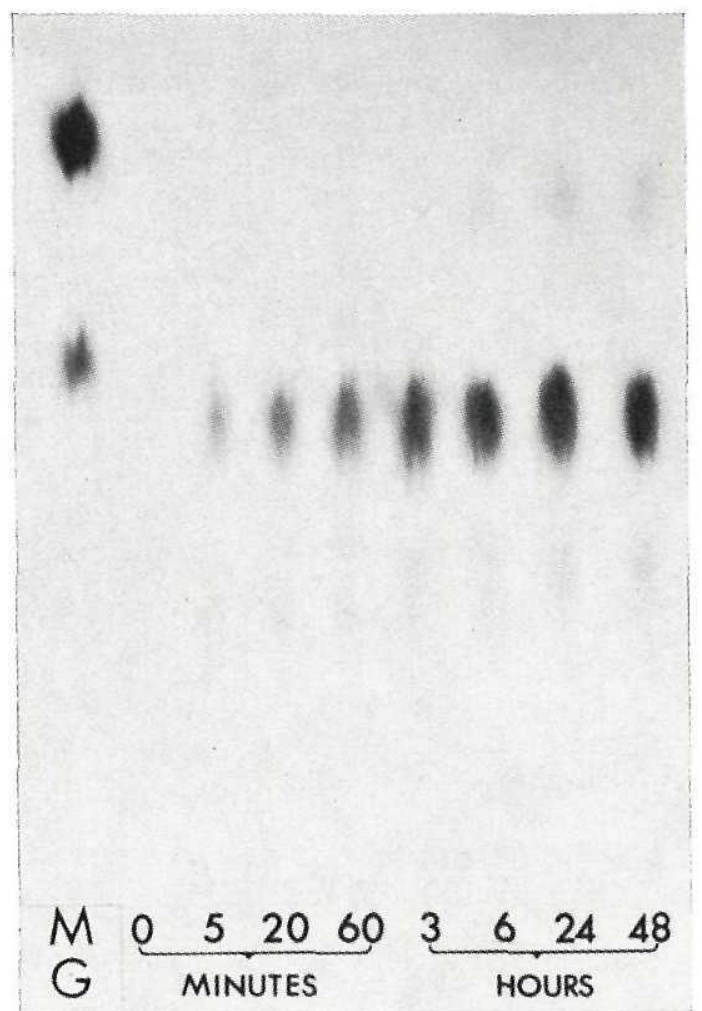

FIG. 1.-Paper chromatogram illustrating that glucose is the principal product when sugarcane amylase acts upon soluble starch. Reference sugars, on left side of chromatogram, appear from top to bottom as follows: Maltose (M) and glucose $(\mathrm{G})$.

saturated with silver nitrate. After drying, these were placed in methanol containing 0.4-percent $\mathrm{NaOH}$ and allowed to remain until spots were clearly defined. Chromatograms were washed and stabilized in 10-percent sodium thiosulfate solution.

\section{RESULTS AND DISCUSSION}

\section{GLUCOSE AS THE PRINCIPAL PRODUCT}

Chromatography of the inactivated digests revealed a single sugar appearing as product within 5 minutes, and continuing as the predominant 
product up to 48 hours (fig. 1). The sugar corresponded closely to reference glucose. This was a major surprise since maltose was anticipated as the principal product. As pointed out earlier, maltose would have appeared had the enzyme attacked alternate alpha $(1 \rightarrow 4)$-glycosidic linkages:

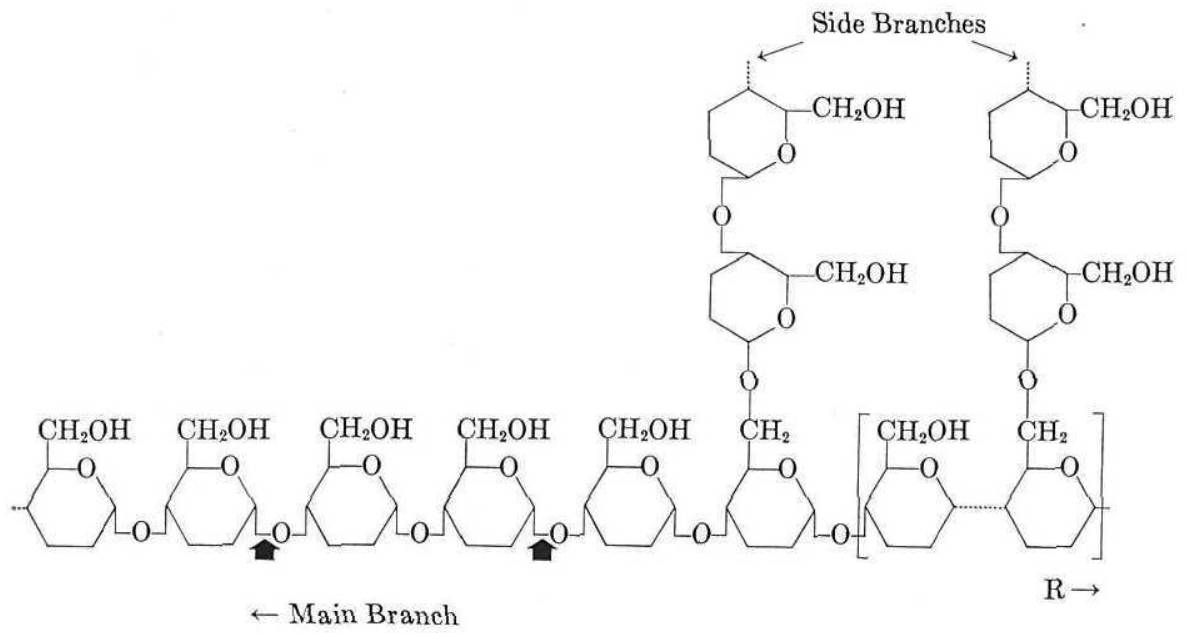

However, it now appears that the alpha $(1 \rightarrow 4)$ linkage was subjected to general hydrolysis at the polymer termini. This likely included those bonds situated toward the ends of side branches:

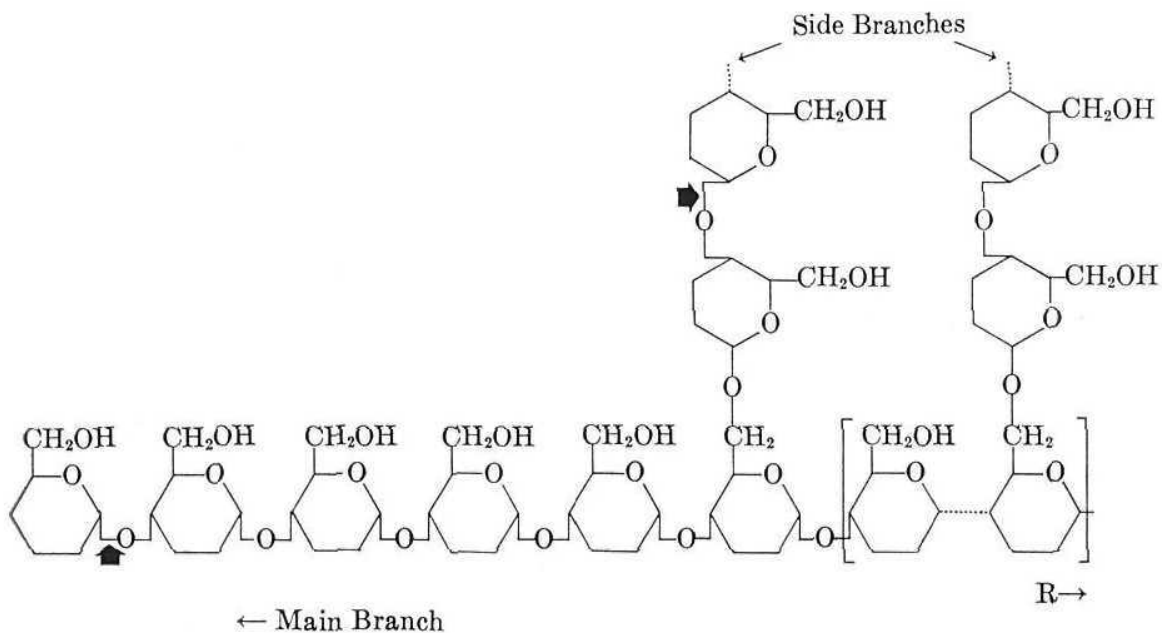

If this were true, the cane enzyme was not behaving in accordance with amylase tradition $(16,17,19)$. An example of specific but multiple amylase action was demonstrated by Dube and Nordin (10) who observed numerous distinct products of sorghum $\alpha$-amylase. These investigators found 
only traces of glucose, which, in turn, was attributed to contaminant glucosidase or maltase arising from mold growth. Later studies showed that sorghum $\alpha$-amylase yielded products with one to eight glucose units (11). A predominance of maltohexose, maltoheptaose, and maltooctaose, was clearly distinguished by paper chromatography.

\section{ABSENCE OF MALTASE}

On the basis of initial results we suspected that a powerful maltase might be acting in conjunction with amylase. Maltase arising as a fungal con-

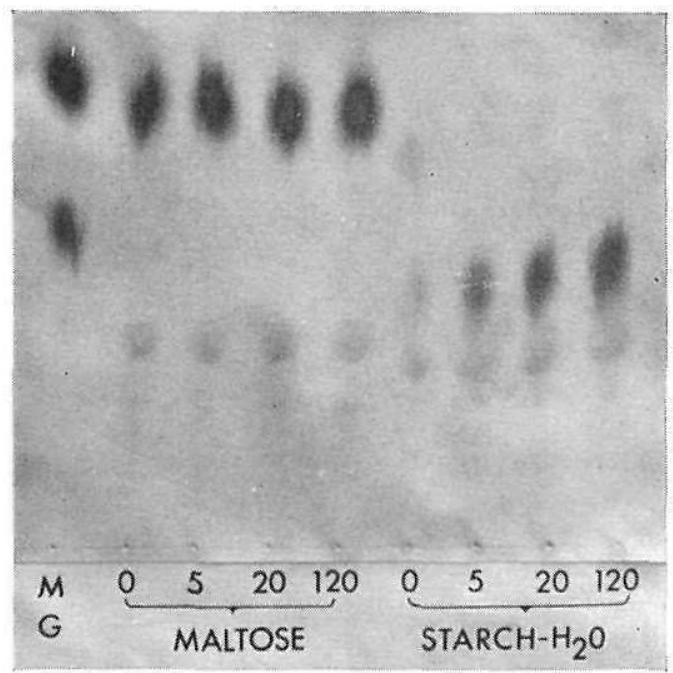

FIG. 2.-Paper chromatogram illustrating the failure of sugarcane amylase preparation to act upon maltose, whereas soluble starch was hydrolyzed to yield glucose. Reference sugars, on left side of chromatogram, appear from top to bottom as follows: Maltose (M) and glucose (G).

taminant was ruled out since glucose appeared within 5 minutes, and all reactions of more than 1-hour duration were conducted under toluene. Nevertheless an endogenous cane maltase might have precipitated with amylase and survived subsequent dialysis. This possibility was investigated by employing both starch and maltose as amylase substrates. Glucose was produced from starch but not from maltose (fig. 2). Maltose therefore could not have been an intermediate product of amylase action.

\section{GLUCOSE PRODUCTION AS RELATED TO AMYLASE SOLUBILITY AND pH}

Although earlier work revealed an acid, $\alpha$-amylase associated with the $\mathrm{Q}$ enzyme (4), we have regarded the bulk of leaf amylase as a beta type. More recent findings have shown two apparently distinct leaf amylases with 

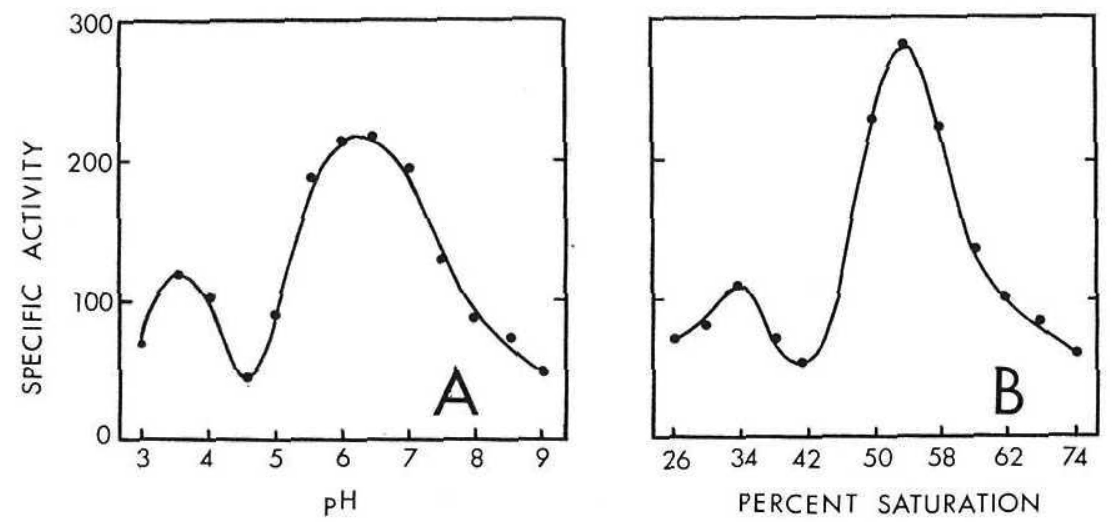

FIG. 3.-Distinct amylase activity peaks in response to variable $\mathrm{pH}$ (A) and solubility in the presence of ammonium sulfate (B).
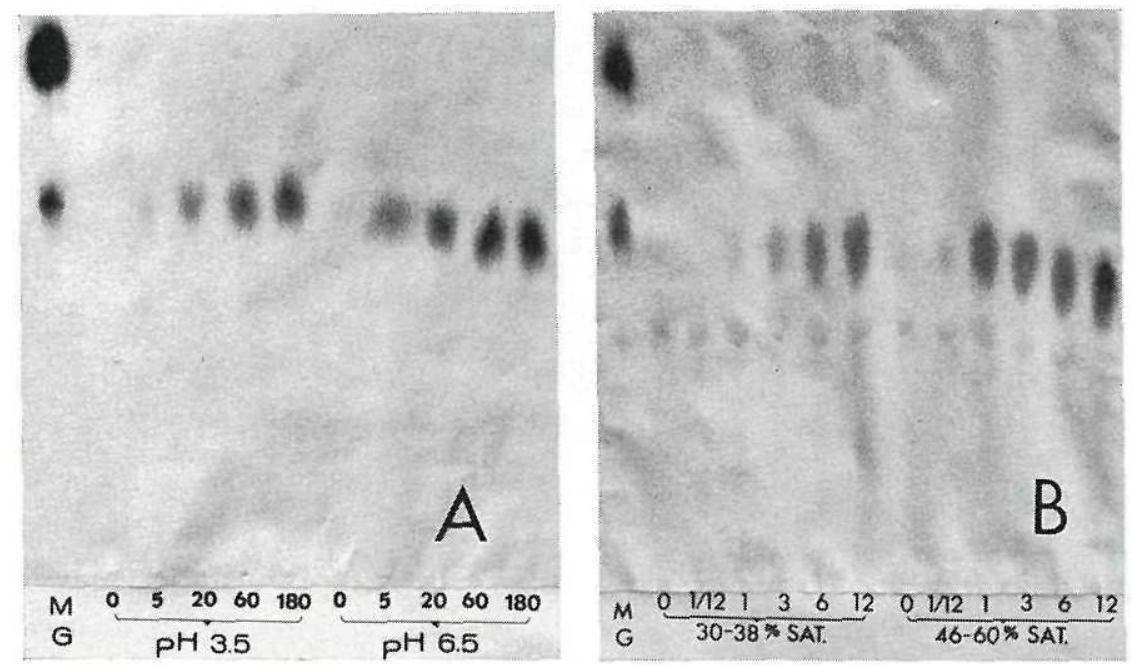

FIG. 4.-Paper chromatograms illustrating glucose as the single product of cane amylase, irregardless of $\mathrm{pH}$ (A) and solubility (B). Reference sugars on left side of chromatogram represent maltose (top) and glucose (bottom).

regard to $\mathrm{pH}$ optima (fig. 3,A) and solubility (fig. 3,B). In particular we felt that the $\mathrm{pH} 3.5$ enzyme might be an alpha type similar to the acid, $\alpha$-amylase encountered by Dube and Nordin in sorghum $(10,11)$ and in barley (10).

Repeated experiments did not reveal action differences with regard either to $\mathrm{pH}$ (fig. 4,A) or solubility (fig. 4,B). In each instance the only product 
was glucose. This need not imply that only a single amylase was present; rather, the production of glucose seems to be a common characteristic of otherwise distinct enzymes.

\section{SUBSTRATES HYDROLYZED}

The cane-leaf amylase preparation was tested against several substrates including soluble potato starch, cornstarch, amylopectin, amylose, inulin,

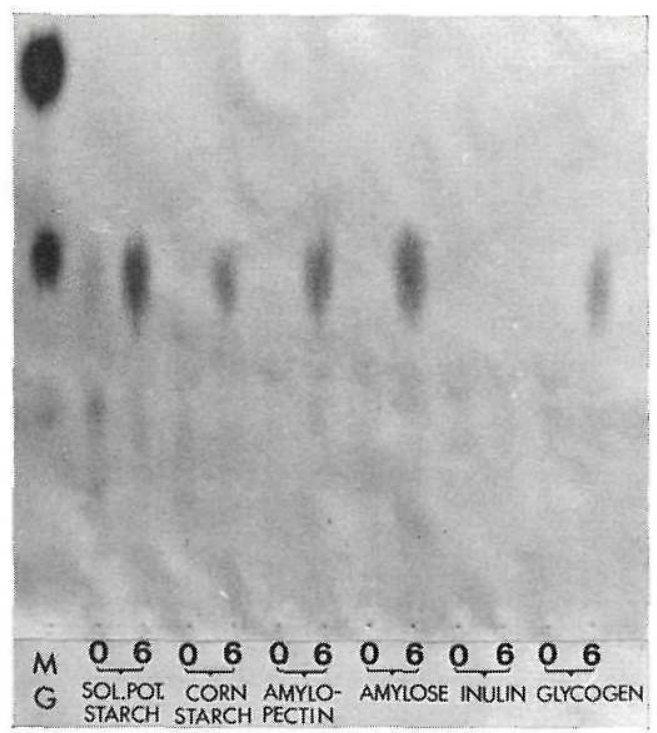

FIG. 5.-Paper chromatogram illustrating glucose as the single product of cane amylase acting upon different substrates. The numerals " 0 " and " 6 " represent reaction periods of 0 and 6 hours, respectively. Reference maltose (top) and glucose (bottom) appear on left side of chromatogram.

and glycogen. Subsequent chromatography showed that, with the exception of inulin, there was a rather indifferent production of glucose alone (fig. 5). The cane enzyme was not deterred by the branched structure of amylopectin, nor by the fact that glycogens are the principal reserve polysaccharides of the animal rather than the plant kingdom. Cane-leaf amylase appears to be a nonspecific glucosidase.

Glycogens are found in cells of all animals. They are abundant in liver and crayfish tissues, and to a lesser extent in muscle, yeast, and higher fungi (20, p. 714). Sweet corn reportedly contains a low molecular-weight amylopectin which is termed "phytoglycogen" in view of its similarity to glycogen (12). Inulin, on the other hand, is one of a group of $d$-fructo- 
furanose polymers which occur in certain plants and is characterized by $2 \rightarrow 1$ linkages between fructose residues. Although unaware of such fructose polymers in sugarcane, the very high levels of fructose found in certain tissues caused us to question whether a hydrolytic catalyst is available to degrade potential fructans. The amylase preparations described herein clearly cannot do this.

\section{PROLONGED HYDROLYSIS WITH HIGH ENZYME CONCENTRATIONS}

The experiments thus far described dealt with relatively short digestion periods and small amounts of enzyme. The glucose produced was probably

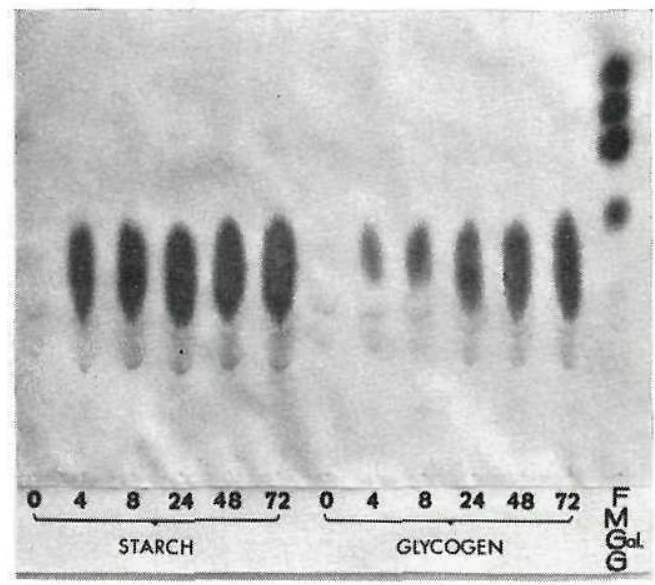

FIG. 6.-Paper chromatography of starch and glycogen digests exposed to high amylase concentrations over a prolonged period. About 48 amylase units were present per milliliter of digest. Reference sugars, on right side of chromatogram, appear from top to bottom as follows: Fructose (F), maltose (M), galactose (Gal.), and glucose $(\mathrm{G})$.

sheared from the ends of polymer chains. If this were so, and particularly in view of the multiple products known for sorghum and barley amylase, one might expect the eventual appearance of numerous oligosaccharides, themselves representing a degree of internal hydrolysis.

This possibility was tested by extending reaction periods up to 72 hours. Enzyme concentration was increased from 10 to 12 to about 48 units per milliliter of digest. Figure 6 illustrates the chromatogramed products obtained when soluble starch and glycogen served as substrate. No clear resolution of products was obtained; rather, a continuous band of reducing sugar extended from the reference site of glucose back through the area of expected oligosaccharides. In the instance of glycogen, this product mass was lengthened markedly as reaction-time increased. Thus a nonspecific 
capability for internal hydrolysis and oligosaccharide formation appeared to exist.

\section{ENZYMATIC ALTERATION OF AMYLASE PRODUCT}

It was recently observed that invertase preparations from cane meristem could readily convert $d$-glucose into another sugar with chromatographic properties similar to those of maltose (8). Conclusive evidence is still lacking, but the sugar is believed to be galactose, and the responsible enzyme an epimerase (galactowaldenase). When extracts of different cane tissues were chromatogramed it was the maltoselike sugar that appeared rather than glucose. Because of this we were interested to note that glucose formed by amylase action remained stable even during the most prolonged reaction periods.

To account for such stability one could say that the product was not truly glucose, but a more likely explanation is that the suspected epimerase is concentrated in meristem rather than in leaf tissues. Also, the extended dialysis treatment given amylase, but not invertase, may have inactivated the glucose-modifying enzyme. We considered that this problem could be greatly clarified by simply inserting invertase preparation into an already active amylase digest. If glucose were in fact formed by amylase, then a secondary product (representing altered glucose) should begin to appear shortly after invertase was added.

An experiment of this type was set up and invertase added after the starch-hydrolyzing reaction had progressed 4 hours. The chromatogramed products are illustrated by figure 7 . Invertase preparations did cause a secondary product to appear, indicating that the initial amylase product was glucose, and that the leaf preparation simply lacked an active enzyme for glucose conversion. Again the secondary product more nearly resembled maltose than galactose, and there is little doubt that maltose was in fact being synthesized from glucose residues. Two other secondary products appeared in small quantities (fig. 7). These may represent a limited attack by invertase upon starch, or perhaps an oligosaccharide synthesis from glucose. Both the glucosidase and invertase reactions in the presence of starch could not have been anticipated from work with other plants.

\section{SIGNIFICANCE OF AMYLASE ACTION IN CANE}

Before the present studies were begun we had already concluded that amylase was needed to help maintain glucose in a nonstorage form. A rather elaborate reaction sequence was proposed which included the enzymes starch phosphorylase, Q-enzyme, $\alpha$ - and $\beta$-amylases, maltase, and hexokinase. Any glucose-1-phosphate that had been diverted from sucrose 
synthesis to polysaccharide formation could be recycled either to sucrose or the Krebs Cycle (7).

Favoring such a pathway is the fact that each of the required enzymes has been found in sugarcane. The sequence might be especially useful in high starch-producing plants such as the potato, corn, barley, or sorghum.
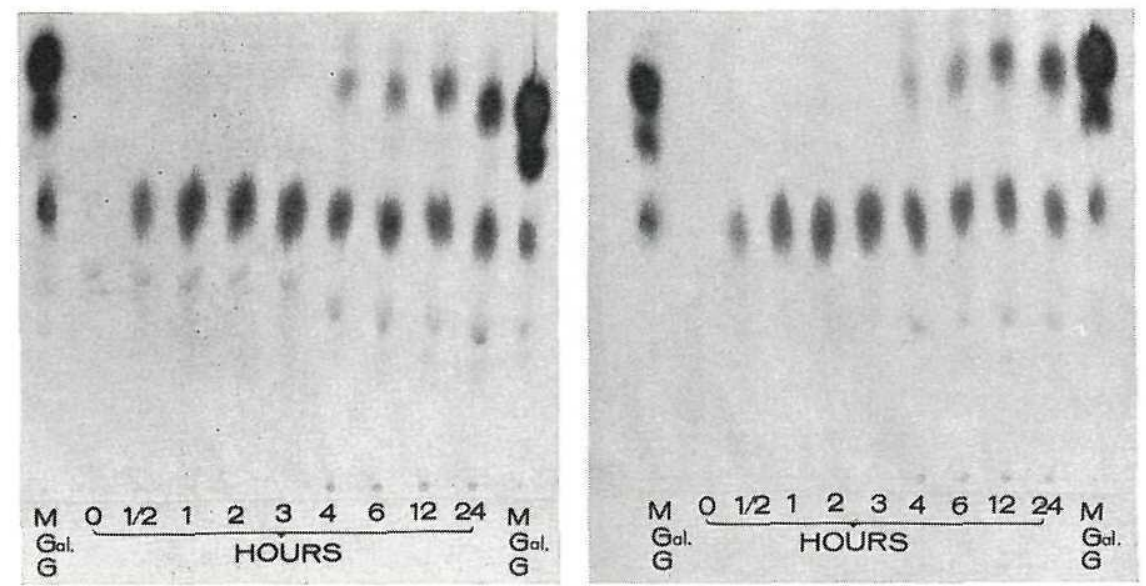

Fig. 7.-Paper chromatograms illustrating glucose produced by cane amylase acting upon starch, followed by cane-invertase preparation acting upon glucose to form maltose. Invertase was added to the digest at 4 hours. Reference sugars, on both left and right sides of chromatograms, appear from top to bottom as follows: Maltose (M), galactose (Gal.), and glucose (G).

Yet on the basis of present findings, the cane amylase role could be much more concise:

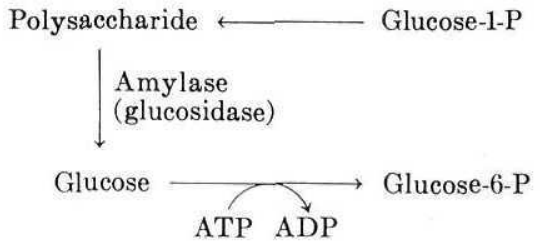

The question of $\alpha v s . \beta$ amylase types becomes purely academic, as does the type of polysaccharide formed from Cori ester. Maltase is not apparently needed at all. The sugarcane plant has provided itself with a direct and powerful means for hydrolysis of glucose polymers.

An important consideration is the type of attack characterizing the cane-leaf amylase. The concept of random attack has been widely held, based upon an enzyme's equal preference for nearly all of the $1 \rightarrow 4$ linkages 
(18). Only those linkages adjacent to the polymer ends and branch points were considered more resistant. However, after chromatographic observation of highly specific oligosaccharides, other workers concluded that a multiple attack occurs in the area of the initial enzyme-substrate encounter $(14,13)$. Nature of the multiple attack is determined by the enzyme, thereby accounting for characteristic oligosaccharide patterns. Dube and Nordin (11) pointed out that random encounter, plus specific multiple attack at the site of encounter, fully explains the action pattern of sorghum $\alpha$-amylase.

Random attack seems to be out of the question with regard to cane amylase since only the single monosaccharide is produced. Random encounter seems probable, yet only at terminal areas is initial hydrolysis taking place. By prolonging the reaction period, and especially by increasing enzyme concentration, internal hydrolysis apparently takes place with the subsequent yield of oligosaccharides. The latter hydrolysis must be highly nonspecific in order to produce a solid mass of reducing sugars such as that illustrated by figure 7 . We conclude that cane amylase experiences random encounter, initial action at polymer termini, and a nonspecific internal action dependent upon enzyme concentration and reaction time.

\section{SUMMARY}

The action pattern of sugarcane leaf amylase was investigated by paper chromatographic techniques. The enzyme was extracted with water from lyophilized leaf tissues, and precipitated by ammonium sulfate between 48- and 60-percent saturation. Aliquots were removed from enzyme-starch digests and inactivated in boiling water at intervals ranging from 5 minutes to 72 hours. Samples were spotted on Whatman No. 1 filter paper, irrigated with butanol-pyridine-water $(6: 4: 3, v / v)$, and products identified by the silver nitrate technique.

The initial and only major product was glucose. No maltose was detected, and oligosaccharides appeared only under conditions of excessively high enzyme concentration or prolonged reaction period. Preparations which appeared to contain distinct amylases on the basis of solubility and $\mathrm{pH}$ optima produced only glucose.

Substrates hydrolyzed included soluble potato starch, cornstarch, amylose, amylopectin, and glycogen. Glucose was the lone product in each instance. Inulin was not attacked. Maltose was not affected by the enzyme preparation.

Glucose produced by enzyme action on starch remained stable. A secondary sugar was formed after invertase preparation was introduced into the digest. This possibly represents an epimerase action upon the newly liberated glucose, but evidence also supports maltose and possibly oligosaccharide synthesis from the glucose product. 
It was concluded that cane amylase is a glucosidase with very general substrate specificity. The action pattern is explained by random encounter of enzyme with substrate, specificity of action at polymer termini, and a nonspecific internal action dependant upon enzyme concentration and time.

\section{RESUMEN}

Se investigó el patrón de acción de la amilasa en la hoja de la caña de azúcar utilizando las técnicas de la cromatografía en papel. La enzima se extrajo con agua de tejidos foliares liofilizados y se precipitó con sulfato de amonio a una saturación entre 48 y 60 por ciento. Se tomaron alícuotas de los digestos de enzima y almidón y se inactivaron en agua hirviendo a intervalos que fluctuaron entre 5 minutos y 72 horas. Las muestras fueron depositadas (spotted) punteando en papel cromatográfico Whatman Núm. 1 de filtrar, bañadas en butanol, piridina y agua $(6: 4: 3 v / v)$; y los productos se identificaron por el método de nitrato de plata.

El producto inicial y único que se obtuvo en cantidad apreciable fué la glucosa. No se determinó la presencia de maltosa y solamente bajo condiciones de concentraciones de enzima excesivamente altas o períodos prolongados de reacción se encontraron oligosacáridos. Se formó únicamente glucosa en preparaciones que aparentemente contenían distintas amilasas de acuerdo con las pruebas de solubilidad y de $\mathrm{pH}$ óptimo.

El almidón soluble de la papa, el almidón del maíz, la amilosa, la amilopectina y el glicógeno fueron los sustratos que se hidrolizaron. En cada caso, el único producto que se obtuvo fué la glucosa. La preparación enzimática no actuó sobre la inulina ni sobre la maltosa.

La glucosa que se produjo por la acción de la enzima permaneció estable. Un azúcar secundario se formó al añadir la preparación de invertasa al digesto. Esto representa posiblemente una acción de la epimerasa sobre la recién formada glucosa, pero también hay evidencia que indica la síntesis de maltosa y posiblemente oligosacáridos del producto de la glucosa.

Se llegó a la conclusión de que la amilasa de la caña es una glucosidasa de acción generalmente específica sobre los sustratos. El patrón de acción se explica mediante el encuentro al azar de la enzima con el sustrato, su acción específica sobre los terminales del polímero, y una acción interna no específica, lo cual depende de la concentración de la enzima y el tiempo.

\section{LITERATURE CITED}

1. Alexander, A. G., Sucrose-enzyme relationships in immature sugarcane as affected by varying levels of nitrate and potassium supplied in sand culture, J. Agr. Univ. P.R. $48(3)$ : 165-231, 1964.

2. - - Physiological studies of enzymes catalyzing the synthesis and hydrolysis of sucrose, starch, and phosphorylated hexose in sugarcane, J. Agr. Univ. P.R. $49(1): 60-75,1965$.

3. - - Behavior of enzymes governing starch- and sucrose-forming pathways in 
two sugarcane varieties supplied with variable nitrate and phosphate in sand eulture, J. Agr. Univ. P.R. 49(2): 153-75, 1965.

4. - - Hydrolytic proteins of sugarcane: The Q enzyme, J. Agr. Univ. P.R. $49(2)$ : 176-203, 1965.

5. - - Hydrolytic proteins of sugarcane: Amylase, J. Agr. Univ. P.R. 49(3): 308-24, 1965.

6. - The biosynthesis of starch in sugarcane, Proc. Intl. Soc. Sugarcane Technol., XII Cong., San Juan, P.R. (in press).

7. - - Las Enzimas, un nuevo Enfoque para Regular las Reacciones Bioquímicas en la Caña de Azúcar, Univ. P.R. Publicación Miscelánea 54, Sept., 1965.

8. - - Action patterns of sugarcane invertase, J. Agr. Univ. P.R. 51(2): 140-53, 1967.

9. Alexander, A. G., and Lebrón, J., Isolation and purification of amylase from sugarcane leaves. (In preparation for publication.)

10. Dube, S. K., and Nordin, P., Isolation and properties of sorghum $\alpha$-amylase, Arch. Biochem. and Biophys. 94: 121-7, 1961.

11. —- The action pattern of sorghum $\alpha$-amylase, Arch. Biochem. and Biophys. 99: 105-8, 1962.

12. Dvonch, W., and Whistler, R. L., Water-soluble polysaccharides of sweet corn, J. Biol. Chem. 181: 889-95, 1949.

13. French, D., Recent developments and theoretical aspects of amylase action, Bakers Digest 31: 24-36, 1957.

14. French, D., and Robyt, J., 140th Meeting Amer. Chem. Soc., Chicago, 1961, Abstr. p. 19C.

15. Fruton, J. S., and Simmonds, S., General Biochemistry, John Wiley \& Sons, New York, N.Y., 1959.

16. Geddes, W. F., The amylases of wheat and their significance in milling and baking technology, Advances in Enzymol. 6: 415-68, 1946.

17. Hopkins, R. H., The action of the amylases, Advances in Enzymol. 6: 389-414, 1946.

18. Myrbäck, K., Products of the enzymatic degradation of starch and glycogen, Advances in Carbohyd. Chem. 3: 251-310, 1948.

19. Myrbäck, K., and Neumuller, G., in Sumner, J. B., and Myrbäck, K., The Enzymes, I, Chap. 19, Academic Press Inc., New York, N.Y. pp. 653-723, 1950.

20. Pigman, W., and Platt, D., in Pigman, W., The Carbohydrates: Chemistry, Biochemistry, Physiology. Academic Press Inc., New York, N.Y., Chap. 12, part II, pp. 709-32, 1957.

21. Sumner, J. B., Dinitrosalicylic acid: A reagent for the estimation of sugar in normal and diabetic urine, J. Biol. Chem. 47: 5-9, 1921.

22. Sutherland, E. W., Cori, C. F., Haynes, R., and Olsen, N. S., Purification of the hyperglycemic-glycogenolytic factor from insulin and from gastric mucosa, J. Biol. Chem. 180: 825-37, 1949. 